\title{
MILITARY HIGHER EDUCATION TEACHING AND LEARNING METHODOLOGIES: AN APPROACH TO THE INTRODUCTION OF TECHNOLOGIES IN THE CLASSROOM
}

\author{
Lúcio Agostinho Barreiros dos SANTOS ${ }^{1,2^{*}}$, Nuno Alberto Rodrigues Santos LOUREIRO ${ }^{1,3}$, \\ Joaquim Manuel Martins do Vale LIMA ${ }^{4}$, José Augusto de Sousa SILVEIRA ${ }^{4}$, \\ Rui José da Silva GRILO ${ }^{4}$ \\ ${ }^{1}$ Military University Institute Research and Development Centre (CIDIUM) Military University \\ Institute, Lisbon, Portugal \\ ${ }^{2}$ Centre for Research in Organizations, Markets, and Industrial Management (COMEGI) Lusiada \\ University of Lisbon, Lisbon, Portugal \\ ${ }^{3}$ Faculty of Sciences and Technology NOVA University of Lisbon, Lisbon, Portugal \\ ${ }^{4}$ Military University Institute, Lisbon, Portugal
}

\begin{abstract}
The study focuses on the use of Information and Communication Technologies (ICT) in Military Higher Education, delimited to the present moment and to the current professors and students of the Military University Institute. This study aims to analyse the relationship between ICT and teaching and learning methodologies in the context of professional military education, with emphasis on the concept of innovation in the classroom, on teaching and learning styles and on the role of ICTs in learning. The study is based on a mixed research strategy combining deductive and inductive approaches, materialized in a case study, with data collected through questionnaires, interviews and documentary analysis. This article focuses on the conceptual framework and its interconnection with the methodological strategy for the empirical study. The results presented refer to the pilot validation test of the data collection instruments and indicate that, in general, students and teachers share the
\end{abstract}

* Corresponding author: labs0892@gmail.com

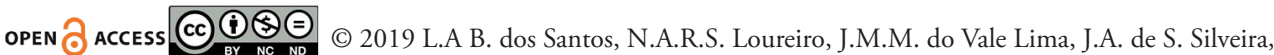
R.J. da S. Grilo, published by War Studies University, Poland.

This work is licensed under the Creative Commons Attribution-NonCommercial-NoDerivatives 4.0 License. 
same teaching-learning styles and both students and teachers show a good propensity to use ICT in the classroom.

Keywords: professional military education, teaching and learning methodologies, information and communication technologies

\section{Introduction}

Education and training in the Portuguese Armed Forces is aimed at preparing the military for the exercise of functions, responding to concrete needs of a military context and, because it is part of the national education system, is subject to evaluation and the procedures of quality management to ensure their continuous improvement.

Military Higher Education (MHE) in Portugal, with special relevance in the Military Sciences, concerns itself with the accomplishment of courses and cycles of studies leading, or not, to the attainment of academic degrees. This teaching aims to prepare highly qualified cadres, developing command, direction and leadership skills to act in situations of risk and uncertainty specific to the missions of the Armed Forces, in response to national and international security and defence requirements. To this end, comprehensive and integrated training of a scientific, technical and technological, behavioural, military, moral and civic nature and adequate physical and psychological preparation essential for the exercise of functions in a military context is required.

MHE is centred on the Military University Institute (MUI), formally created in October 2015 , as a military university whose mission is to develop teaching, research, community support, cooperation and exchange activities with the aim of training officers and sergeants of the cadres' permanent members of the Armed Forces, qualifying them with the appropriate competencies for the functions assigned to them.

Many of today's challenges are related to the breadth and diversity of knowledge, skills and attitudes required, and to the indispensable reflection on the most appropriate methodologies to promote and enhance the learning of new generations of officers. In a changing environment and with the notion that new generations (e.g. Millennials and Zeds) learn differently from previous generations, the increasing use of ICT in teaching in a military context can more easily bring together training objectives and focus in the selection and integration of the best technological tools for a high educational return. 
In this context, the use of ICT is instrumental and unavoidable because it facilitates innovation and renewal of institutions and provides gains in efficiency and effectiveness. The new technologies allow new uses and experiences in a training environment, in "Classroom"1 (in its physical and virtual dimensions), which were previously impossible. Despite a whole range of new technological possibilities, the teacher continues to play a key role, although now with new contours. In this sense, the preparation of the "military teacher" must be systematically rethought and updated so as to incorporate the knowledge, skills and attitudes necessary to the functional requirements of each moment, adequate for the teaching of key military competences for the 21 st century.

The study object of this research is MHE, ICT and its role in the teaching and learning process, and is delimited (Santos and Lima 2016), at three levels:

- Temporally, to the academic year of 2018/2019;

- Spatially, to all students and professors, of the three branches of the Armed Forces, who attend or teach, respectively, in the academic year 2018/2019, the Course for Promotion to Senior Official (CPOS), Joint Staff (CEMC) and the Promotion Course to General Officer (CPOG);

- Conceptually, in the analysis of the relationships between the students' learning styles and the teaching styles of the teachers, the attitude of students and teachers to the introduction of ICT in the classroom and the adequacy of new teaching and learning methodologies curricular areas.

In line with the above, it was defined as a general objective of the research to analyse the ESM, with a special focus on the concept of innovation in the "Classroom", based on teaching and learning styles, the role of ICT and its adequacy for military vocational education.

In this sense, it is important to analyse some relationships that are established between the key variables of the study, which are expressed from some specific objectives (SO), in relation to which the respective hypotheses will be adduced:

1 The traditional classroom concept presents it as a space, usually a room of variable dimensions, with environmental, dispositional, work and study conditions, where the formal teaching and learning process takes place, whose development dates back to the last century with the democratisation of access to education. (Garrido 2006) The "Classroom" concept of the future was created in 2011 under the iTEC Project under the coordination of the European Schoolnet, with the purpose of designing a new proposal of organisation of classroom space and practices, by harmonious conjugation of three key elements: Space, Technology and Pedagogy. (Lewin and McNicol 2014) 
SO1: Identify and relate the students' learning styles and teachers' teaching styles in order to understand their impact on the teaching and learning process;

SO2: Identify and analyse the attitudes of both students and teachers towards the increased use of ICT in the "Classroom" in order to understand their impact on the teaching and learning process;

SO3: To evaluate the appropriateness of the new teaching and learning methodologies resulting from the use of ICT in the "Classroom", to the curricular areas, in order to identify opportunities for their introduction into the teaching and learning process.

The study seeks to answer the following research questions:

1. What are the learning styles preferred by the students and what are the teaching styles adopted by the teachers, what is the relationship between them and how do they contribute to the teaching and learning process?

2. What are the attitudes of students and teachers towards the use of ICT in the "classroom", what is the relationship between them and how do they contribute to the teaching and learning process?

3. Which, among the new teaching and learning methodologies that integrate ICT, are the most appropriate to the curricular contents of the ESM?

In the present article we intend, essentially, to develop the conceptual framework and its interconnection with the methodological strategy, that is the definition of the instruments of data collection for a complete empirical study to be developed. In this way, the results presented now refer to the pilot test for validation of these same data collection instruments.

To this end, the article is structured in three chapters, in addition to the introduction and conclusions. Initially, a review of the literature is under way, highlighting the new challenges facing higher military education in the face of the VUCA ${ }^{2}$ context of today, the importance of technology in the development of new teaching and learning methodologies, and the emergence of new learning environments. Secondly, a detailed description of how the study is being conducted is given, including an explanation of the concepts and the operationalisation of the variables under study. Next, the preliminary data collected is summarised, characterising the sample and analysing the relevance of the data collected.

2 Concept introduced by U.S. Army War College to describe the multilateral world resulting from the end of the Cold War: Volatile, Uncertain, Complex and Ambiguous. 


\section{Literature Review}

\section{The New Challenges of Higher Military Education}

The military profession, analysed from a vocational or professional perspective (Moskos et al. 2000), requires a broad set of very comprehensive competencies for the military to fulfil its duties and obligations, within its demanding functions of command, direction, leadership, staff and execution, among others.

In the structuring of career development (normative model), several courses are planned with the purpose of enabling the military with adequate knowledge throughout their professional career. In this sense, the military institution must have well-defined professional profiles developed at the level of the different categories, specialties and functions, with concrete competences (some transversal and others specific) and with clearly differentiated levels of demand (Ministério da Defesa Nacional 2015).

The training given should be in line with what the military must do to fulfil the mission, that is what it is that they must learn, and then see if they have learned and can apply what they have learned. Thus, training in a systemic approach should include four steps: analysis, curriculum design, development and implementation. In the construction of course references, functional analysis is essential and takes into account the work context, organizational systems, functional relations and their future application (Exército Português 2014).

The Military Committee of the European Union and the European Security and Defence College have developed a qualifications framework for the military professions, in line with the European Qualifications Framework. To date, as a result of the European Initiative for the Exchange of Officers under the Erasmus programme, a competencybased qualification framework for young officers trained by the Military Academies or similar has been developed and has resulted in the identification and development of eight areas of competence: military service; technician; leader and decision maker; combatant; communicator; teacher / tutor; critical thinker and researcher; international security / diplomacy actor (Bielewicz and Pietrakowski 2016, EEAS 2018).

This work of harmonisation and external recognition of competencies for all officers of member countries presents some challenges for the Armed Forces, since it establishes that 
a superior officer (lieutenant-commander / major / commander / lieutenant-colonel) must have a degree equivalent to $\mathrm{PhD}$. It is also important to understand what the consequences are in terms of career development, namely whether or not the doctoral degree is required for promotion to a colonel.

Another challenge facing the Armed Forces is related to the comprehensiveness and demands of knowledge, since it is increasingly necessary to develop more complex knowledge, skills and attitudes, such as: demonstrating critical knowledge and understanding of military operations; implement different joint military capabilities; demonstrate a deep understanding of the operational planning process, the rules of engagement, and risk management; understand and deal with the complexity and diversity of tasks; be very adaptable to different positions and functions, in contexts of change and new challenges; demonstrate authority, autonomy, professional integrity, sustained commitment to the development of processes at the forefront of work and innovation. Therefore, it is important to analyse the course references and review them in order to adapt them to these new requirements.

Another challenge that arises, especially related to the new generations, is the reflection on the most appropriate methodologies that promote and enhance learning in the new generations of officers, and thus incorporate the latest trends and the innovation that occurs in the environment of learning, which will be addressed in a future paper.

\section{The Role of Technology in Teaching and Learning}

According to the Dictionary of the Portuguese Language of Porto Editora, the term "technology" refers to the "set of instruments, methods and techniques that allow the practical use of scientific knowledge", and are used to solve problems or achieve goals. In the classroom, technology can span all types of tools, from "low" pencil, paper or blackboard technology to the use of presentation software or high-tech tablets, collaborative tools, online conferencing and much more. The latest technologies allow us to experiment with methodologies in classrooms, both physical and virtual, that were not previously possible, depending fundamentally on what we want to accomplish.

Teaching with technology can deepen student learning by supporting training objectives. However, it can be a huge challenge to select the "best" technology tools without losing 
sight of the learning objectives. Once identified, the integration of these tools can also be another challenge, although it can become an experience with high educational returns.

How can technology help? Online collaborative tools allow students and instructors to share documents online, edit in real time, and project on a screen. This gives students a collaborative platform for the exchange of ideas and the possibility of documenting their work using text and images. The presentation software allows instructors to incorporate high resolution photographs, diagrams, videos and sound files to increase text content and verbal lessons. Tablets can be connected to computers, projectors, and the cloud so students and teachers can communicate through text, drawings, and diagrams. Course management tools allow instructors to organise all the resources required for a class (programmes, tasks, readings, online tests), provide valuable assessment tools, and create spaces for discussion, document sharing, and audio and video commentary. Smartphones provide a quick and easy way to get feedback from students during class. This is great for instant surveys, which can quickly assess student understanding and help instructors adjust pace and content. Capture tools allow instructors to record lectures and lectures directly from your computer, without elaborate or additional classroom equipment. Some studies show that in general, the use of recorded lessons does not reduce the frequency of students attending in-person classes, and that they actually appreciate the possibility of reviewing them at their own pace (Karnad 2013).

\section{Technology and New Teaching-Learning Methodologies}

It is common to find some reluctance in the Institutions of Higher Education regarding the adoption of new procedures, processes and models of teaching-learning, as it is sometimes more common for a conservative position to exist in a military institution. According to Cathy Downes (2015, p. 107), "enabled by technology advances, new understandings about teaching and learning have evolved that improve the quality of the learning experience. [...] However, in comparison to many other sectors, the higher education sector has evolved very slowly and in a very patchy way."

But the recovery of the backwardness that may exist in higher education institutions, whether civilian or military, may, perhaps, be based on a strategy, not to go through all unfulfilled development stages, but to neglect the intermediate and try as much as possible to keep abreast of the current stage of scientific and technological development 
by adopting new technologies to support the teaching-learning process. It may, however, be necessary to evaluate the implications of "burning" some steps.

Downes notes that the emergence of WEB 3.0 has led to the emergence of Learning 3.0, admitting that it is certainly still in the experimentation period, but at the same time saying that this situation allows the main technologies of WEB 2.0 to evolve, taking advantage of the emerging technologies of WEB 3.0, for which the author identifies three characteristics that, according to her, will probably shape the functionalities of Learning 3.0: (1) "mobile technologies that are making learning anywhere, anytime possible"; (2) "maturing Web 2.0 applications and Semantic Web technologies, along with Internet infrastructure developments, that are always-on personalised / personal learning networks, and alternative educational digital-based spaces and facilities possible"; and (3) "data web technologies that are likely to influence how educational institutions measure, evaluate, analyse, and adapt group and individual learning experiences." (Downes 2015).

Another perspective on the role of technology in the teaching-learning process is brought to us by Peter J. Denning and Susan L. Higgins. In dealing with the topic Being in Uncertainty: Cultivating a New Sensitivity in Military Education, these authors report a marked increase in the discussion of technological advances in learning environments, in particular the Massive Open Online Courses (MOOC) Internet-based platforms that make it possible to make university courses freely available around the world using an automated personalised response system, thus being an Automated Learning Environment (ALE). They also point out that the Online Competency Based Module (OCBM) is a promising technology- presented as a new nonlinear learning mode, called hyper learning, which is concerned with teaching and testing students for certain specific skills in a given domain of knowledge, then issuing a certificate of competence to those who succeed in the tests to which it is subject, and this certificate is offered as an alternative to a university degree (Denning and Higgins 2015).

These authors also point out that in a military context, senior leaders are asked to go beyond basic skills and are required to be at least at the "proficient" level, which cannot be achieved by recourse to a mere ALE, for those leaders work in environments where rules are constantly changing. The authors point out that the challenge in military education is to go beyond technologies when trying to develop higher levels of leadership (Denning and Higgins 2015). 
Another relevant aspect when talking about the use of technology to support and build new learning environments is the role that industry and research and development have played in developing or even creating products that educational institutions can use with significant gains in the efficiency and effectiveness of the training process. However, according to Neal (2015, p. 165), although there has been a growing use of simulators in training programmes aimed at familiarising trainees with new equipment, care should be taken to evaluate in advance the contexts of training in which this use effectively allows gains in effectiveness and those in which this does not happen. As an example, this author points out that topics related to military doctrine, politics or history are typically treated through lectures, discussion and debate, and should not be treated by technological products that would be downright inappropriate.

As Schatz et al. (Schatz et al. n.d.) argue in the article The Changing Face of Military Learning, the military context requires a permanent development of skills in its staff, and this process is also based on the teaching and training given to them: "military personnel require an expanded set of competencies, higher levels of nuanced skills such as critical thinking and emotional intelligence, and more efficient and agile pathways to expertise, and that achieved at least in part depends on revising the military learning enterprise".

\section{Emerging Learning Environments}

Referring to WEB 2.0 technology, Foon Hew and Sum Cheung (2013, p. 48) state that this is an interactive tool that facilitates bidirectional interaction, requiring the students to contribute a contribution in the placement of information on the site available, interacting and sharing their ideas and knowledge in a collaborative way. According to the authors, the technological tools of WEB 2.0 allow teachers to apply a constructivist approach to teaching and learning. There are three possible ways to use WEB 2.0 tools within the scope of teaching: (1) Blogger: is a blogging tool whose function is to provide a platform for students to create and share their ideas and their reflective thoughts while having access to feedback for their self-improvement at the level of understanding; (2) Active Worlds: social virtual worlds are a learning space that requires students to be the active elements in creating and designing an environment that allows them to learn by doing, students are in control and, in a 3D world, options are endless; and 
(3) Teachertube: allows students, individually or in groups, to upload and share their projects / videos / documents / audios and others with a secure educational community (teachers and students) that also provides a content library educational (Bower et al. 2010 cited by Hew and Cheung 2013, Foon Hew and Sum Cheung 2013).

The potential of the WEB 2.0 tools being developed seem to be endless, as they allow students to share learning experiences in a public format that can be attractive to other students and provide a playful way of learning. On the other hand, the students also have a responsibility to the extent that they are required to contribute to society. It is in this sense that Pinel (2017) states that students are required to acquire 21 st century ICT skills because they are related to the real world, develop as students construct knowledge, and contribute to society.

An Australian publication on educational technology edited by Education Technology Solutions (ETS), recently published an online article entitled Technology That Will Shape Education In 2017 (Low 2017), in which it presented a guide to the main trends in educational technology that will have a relevant impact on learning and teaching. The technologies presented here are: Virtual Reality, Augmented Reality, Learn from Anywhere, Teaching from Anywhere Mobile Devices, Collaboration Technology, Gamification, Coding, Evolving Learning Spaces and Styles, and The Maker Movement. The article concludes by saying that the aforementioned Edu-tech tendencies show that the way in which education professionals learn, teach and collaborate is changing significantly.

\section{Learning Styles}

The assimilation and processing of information and knowledge is different from individual to individual. They can do this by seeing or hearing, reflecting or acting, reasoning in a logical or intuitive way, analysing or visualising. Students have different strengths and preferences in how they receive and process information, which means that they have different learning styles (Felder and Spurlin 2005).

In 1988, Richard Felder and Linda Silverman formulated a model designed to identify the most important differences in learning styles among engineering students and provide a good basis for their teachers to formulate a teaching approach that meets the learning 
needs of all the students. As the authors themselves put it, the proposed dimensions were not original. For example, the first dimension - sensory / intuition - is one of the four dimensions of a well-known model based on the theory of Jung's psychological types, and the fourth dimension - active / reflexive processing - is a component of the developed learning style model by Kolb. Other dimensions of these two models and dimensions of other models also play important roles in determining how a student receives and processes information (Felder and Silverman 1988).

Teaching methodologies also vary, with some teachers preferring lectures and others favouring demonstration or leading students to self-discovery; some focus on principles and others on applications; some emphasise memory and others emphasise understanding. Difficulties arise when there are incompatibilities between the student's learning styles and the teacher's teaching style, students may become bored and inattentive in class, perform poorly in tests, and lose motivation regarding courses and curriculum. (Soloman and Felder 1996, 1999) Empirical studies have confirmed the hypothesis that teachers who are able to adapt their teaching style to include the two poles of each dimension, ideal for most (if not all) students in a class (Felder and Spurlin 2005).

The Felder and Silverman model, in the 2002 update, ranks a student's learning style from one category or another in each of the four dimensions through the answers given to four questions:

1. What kind of information does the student preferentially perceive: sensory (visions, sounds, physical sensations, concrete, practical, fact-oriented and intuitive thinking) or intuitive (possibilities, perceptions, hunches, abstract thinking, innovative, oriented to theories and meanings underlying)?

2. Through which sensitive channel is the most effectively perceived external information: visual (prefer visual representations of displayed material such as figures, diagrams, flowcharts, graphs, demonstrations) or verbal (prefer written and spoken explanations)?

3. How does the student prefer to process information: actively (through involvement in physical activity or discussion, experiencing things, working in groups) or reflexively (through introspection, prefer to work alone or with a single family partner)?

4. How does the student progress towards understanding: sequentially (linear thinking process, learning in small incremental steps in continuous steps) or globally (holistic thinking process, learning in big leaps)? 
The same model states that teaching style can also be defined, in one or another category of each of the four dimensions, in terms of answers to four questions:

1. What kind of information is emphasised by the teacher: concrete (factual) or abstract (conceptual, theoretical)?

2. Which form of presentation is preferred by the teacher: visual (visual images, diagrams, films, demonstrations) or verbal (verbal talks, readings, discussions)?

3. What mode of student participation is facilitated by the teacher's presentation: active (do students speak, move, or reflect) or passive (do students watch and listen)?

4. What kind of perspective is provided on the information presented: sequential (step by step, showing "the trees") or global (relevance (presenting "the forest")?

Table 1 summarises learning and teaching styles in their different dimensions and categories, as proposed by Felder and Silverman (Felder and Silverman 2002).

\section{Table 1. Learning and Teaching Styles Dimensions and Categories}

\begin{tabular}{|c|c|c|c|}
\hline \multicolumn{2}{|c|}{ Preferred Learning Style (student) } & \multicolumn{2}{|c|}{ Corresponding Teaching Style (teacher) } \\
\hline Categories & Dimensions & Categories & Dimensions \\
\hline $\begin{array}{l}\text { Sensory } \\
\text { Intuitive }\end{array}$ & Perception & $\begin{array}{l}\text { Concrete } \\
\text { Abstract }\end{array}$ & Content \\
\hline $\begin{array}{l}\text { Visual } \\
\text { Verbal } \\
\end{array}$ & Input & $\begin{array}{l}\text { Visual } \\
\text { Verbal }\end{array}$ & Presentation \\
\hline $\begin{array}{l}\text { Active } \\
\text { Reflexive }\end{array}$ & Processing & $\begin{array}{l}\text { Active } \\
\text { Passive }\end{array}$ & Student participation \\
\hline $\begin{array}{l}\text { Sequential } \\
\text { Global }\end{array}$ & Understanding & $\begin{array}{l}\text { Sequential } \\
\text { Global }\end{array}$ & Perspective \\
\hline
\end{tabular}

\section{Acceptance of Technology in the Classroom}

Barriers to acceptance of ICT integration, defined as user intent and / or actual use of technology, were compiled by Gu, Zhu, and Guo (2013) into four constructs often referred to as predictors of ICT acceptance: expectation of results, adjustment of technology to task, social influence and personal factor. 
Outcome Expectancy results from internal beliefs and attitudes about the use of ICT; it is measured as perceived utility and perceived ease of use, being considered the most important predictor of the use of technology. Task-Technology Fit is the degree to which a technology helps an individual accomplish his or her tasks. It is based on the assumption that users accept the technology because of its potential benefits, such as performance improvement, regardless of their attitude. Social influence is a type of social norm defined as "perceived social pressure to carry out behaviour or not" (Ajzen 1991 cited by Gu et al. 2013). Personal Factors constructed include self-efficacy with the computer and propensity for technological innovation.

\section{Methodology}

The study is based on a mixed research strategy (Creswell 2013) combining hypotheticaldeductive (Quivy and Campenhoudt 2008) and inductive (Creswell 2012) approaches, materialised in a cross-sectional study (Bryman 1988), with data collected at a given moment, through questionnaires, interviews and documentary analysis.

Due to the temporal, spatial and conceptual boundaries defined for this research, the target population of the present study is composed of students and professors of the CPOS, CEMC and CPOG, of the Military University Institute, in the academic year 2018/2019.

As previously mentioned, this article focuses mainly on the conceptual framework and its interconnection with the methodological strategy for the empirical study, and the preliminary results presented are based only on the pilot test, submitted to a convenience sample composed of the students and professors of the CPOS, CEMC and CPOG, of the Military University Institute, in the academic year 2017/2018.

\section{Questionnaire}

For the empirical study, a data collection instrument was prepared based on the following scales: (1) Index of Learning Styles (ILS), proposed by Soloman and Felder (Soloman and Felder 1999); and (2) Technology Acceptance Barriers (TAB), proposed by Gu, 
Zhu, and Guo (Gu et al. 2013). It was also complemented by ad hoc items designed to collect biographical and professional data on the one hand and, on the other hand, to verify the traditional teaching methodologies currently used in curricular areas and to identify the most appropriate ICT-based teaching methodologies to each of the specific curricular areas.

The Index of Learning Styles is an online research tool used to evaluate preferences in four dimensions (active / reflexive, sensory / intuitive, visual / verbal and sequential / global), built from the model of learning styles formulated by Felder and Silverman (Felder and Silverman 1988, 2002). The scale was developed and validated by Felder and Soloman (Soloman and Felder 1996, 1999). In their original version, respondents respond online to 44 questions, with two alternative answers, "a" and "b", and submit responses online, and receive a report on their preferences regarding the four dimensions under review.

The Technology Acceptance Barriers questionnaire is an instrument that intends to measure the extent and nature of the barriers to the integration of ICT in the perspective of technology acceptance. For their construction, the authors (Gu et al. 2013) examined the various factors that influence the acceptance of technology and compiled four constructs, which have often been mentioned as predictors of the same acceptance of ICT: Outcome Expectancy, , Task-Technology Fit, Social Influence, and Personal Factors. The items for these constructs were developed by adapting instruments from previous studies. In the present case, the questionnaire was adapted to the Portuguese language and to the military context, resulting in eight items to measure the expectation of results and the expectation of interest in learning and retention; the adjustment of the technology to the tasks was measured with five items, covering the aspects of work compatibility, ease of use and quality of information; social influence was measured by four items that referred to participants 'beliefs about the organisation's or peers' support for ICT use (in this construct, the item on family support was withdrawn because it was considered to be of little relevance); and the personal factor was measured with seven items, four self-efficacy with the computer and three personal innovation with ICT. All items were measured using a 7-point Likert scale ranging from "strongly agree" to "strongly disagree". 
Regarding the ad hoc items introduced in the questionnaire, some questioned the three most traditional teaching methodologies ${ }^{3}$ currently used in each curricular area; others questioned the three ICT-based teaching methodologies ${ }^{4}$ best suited to each of the specific curricular areas.

The questionnaire, necessarily different between students and teachers, after a brief introduction explaining the objectives of the study and guaranteeing the treatment of the data in an anonymous and confidential way, and its exclusive use for the mentioned effects, was thus composed of the four shown in Table 2.

Table 2. Questionnaire's character and number of items

\begin{tabular}{|l|l|l|l|}
\hline Students & Teachers \\
\hline $\begin{array}{l}\text { Section A - Biographical and } \\
\text { professional data (control } \\
\text { variables: age, sex, effective service } \\
\text { time, branch, course attended). }\end{array}$ & Total - 5 items & $\begin{array}{l}\text { Section A - Biographical and } \\
\text { professional data (control } \\
\text { variables: age, sex, effective } \\
\text { service time, branch, time in } \\
\text { teaching functions, course } \\
\text { teaching, specific teaching } \\
\text { training) }\end{array}$ & Total - 7 items \\
\hline $\begin{array}{l}\text { Section B - Learning Styles } \\
\text { Index: Identify students' learning } \\
\text { preferences. }\end{array}$ & $\begin{array}{l}11 \text { items per } \\
\text { dimension } \\
\text { Total - 44 items }\end{array}$ & $\begin{array}{l}\text { Section B - Teaching Styles } \\
\text { Index: Collect teachers } \\
\text { 'perceptions about students' } \\
\text { learning preferences. }\end{array}$ & $\begin{array}{l}11 \text { items per } \\
\text { dimension } \\
\text { Total - 44 items }\end{array}$ \\
\hline $\begin{array}{l}\text { Section C - Barriers to } \\
\text { Technology Acceptance: Identify } \\
\text { students' propensity to use } \\
\text { technology in learning. }\end{array}$ & $\begin{array}{l}\text { OE - 8 items } \\
\text { PF - 7 items } \\
\text { TTF - 7 items } \\
\text { SF - 4 items } \\
\text { Total - 26 } \\
\text { items }\end{array}$ & $\begin{array}{l}\text { Section C - Barriers to } \\
\text { Technology Acceptance: } \\
\text { Identify teachers' propensity to } \\
\text { use technology in learning. }\end{array}$ & $\begin{array}{l}\text { OE - 8 items } \\
\text { PF - 7 items } \\
\text { TTF - 7 items } \\
\text { Sotal - 26 items }\end{array}$ \\
\hline
\end{tabular}

3 Lesson / Lesson Debate; Directed Discussion / Learning Discussion / Topic Discussion; Individual Application Work / Application Work Group; CPX / CAX Computer Assisted; Field Exercises; Field trip; Seminar / Panel / Symposium; Workshop; Lecture / Conference / Cycle of Conferences; Presentation and Defence of Work.

4 Digital Book; Ongoing training online; Gamification; Project Based Learning (PBL); Case study; Team Based Learning (TBL); Flipped Classroom; Coding; Virtual reality; Computer Based Training (CBT); Augmented Reality; Learn from anywhere / Teach from anywhere Mobile Devices. 


\begin{tabular}{|c|c|c|c|}
\hline Students & & Teachers & \\
\hline $\begin{array}{l}\text { Section D1 - Identify the current } \\
\text { teaching / learning methodologies } \\
\text { most appropriate to the curricular } \\
\text { context of the CPOS, CEMC and } \\
\text { CPOG, for each of its curricular } \\
\text { areas: } \\
\text { - Lesson / Lesson-Debate; } \\
\text { - Directed Discussion / Learning } \\
\text { Discussion / Topic Discussion; } \\
\text { - Individual Application Work / } \\
\text { Application Work Group; } \\
\text { - Computer Assisted CPX / } \\
\text { CAX; } \\
\text { - Field Exercises } \\
\text { - Field trip } \\
\text { - Academic Seminar / Panel / } \\
\text { Symposium } \\
\text { - Workshop } \\
\text { - Lecture / Conference / } \\
\text { Conference Cycle } \\
\text { Presentation and Defence of } \\
\text { Work }\end{array}$ & $\begin{array}{l}\text { CPOS - } 9 \text { items } \\
\text { CEMC }-16 \\
\text { items } \\
\text { CPOG }-14 \\
\text { items }\end{array}$ & $\begin{array}{l}\text { Section D1 - Identify the } \\
\text { current teaching / learning } \\
\text { methodologies most } \\
\text { appropriate to the curricular } \\
\text { context of the CPOS, CEMC } \\
\text { and CPOG, for each of its } \\
\text { curricular areas: } \\
\text { - Lesson / Lesson-Debate; } \\
\text { - Directed Discussion / } \\
\text { Learning Discussion / Topic } \\
\text { Discussion; } \\
\text { - Individual Application Work } \\
\text { / Application Work Group; } \\
\text { - Computer Assisted CPX / } \\
\text { CAX; } \\
\text { - Field Exercises } \\
\text { - Field trip } \\
\text { - Academic Seminar / Panel / } \\
\text { Symposium } \\
\text { - Workshop } \\
\text { - Lecture / Conference / } \\
\text { Conference Cycle } \\
\text { - Presentation and Defence of } \\
\text { Work }\end{array}$ & $\begin{array}{l}\text { CPOS - } 9 \text { items } \\
\text { CEMC - } 16 \\
\text { items } \\
\text { CPOG - } 14 \\
\text { items }\end{array}$ \\
\hline $\begin{array}{l}\text { Section D2 - Identify the new } \\
\text { teaching / learning methodologies } \\
\text { best suited to the curricular } \\
\text { context of the CPOS, CEMC and } \\
\text { CPOG, for each of its curricular } \\
\text { areas: } \\
\text { - Digital Book. } \\
\text { - Ongoing training online. } \\
\text { - Gamification. } \\
\text { - Project Based Learning (PBL). } \\
\text { - Case study. } \\
\text { - Team Based Learning (TBL). } \\
\text { - Flipped Classroom. } \\
\text { - Encoding. } \\
\text { - Virtual reality. } \\
\text { - Computer Based Training } \\
\text { (CBT). } \\
\text { - Augmented Reality. } \\
\text { Learn from anywhere / } \\
\text { Teach from anywhere Mobile } \\
\text { Devices. }\end{array}$ & $\begin{array}{l}\text { CPOS - } 9 \text { items } \\
\text { CEMC - } 16 \\
\text { items } \\
\text { CPOG - } 14 \\
\text { items }\end{array}$ & $\begin{array}{l}\text { Section D2 - Identify the } \\
\text { new teaching / learning } \\
\text { methodologies best suited to } \\
\text { the curricular context of the } \\
\text { CPOS, CEMC and CPOG, } \\
\text { for each of its curricular areas: } \\
\text { - Digital Book. } \\
\text { - Ongoing training online. } \\
\text { - Gamification. } \\
\text { - Project Based Learning } \\
\text { (PBL). } \\
\text { - Case study. } \\
\text { - Team Based Learning (TBL). } \\
\text { - Flipped Classroom. } \\
\text { - Encoding. } \\
\text { - Virtual reality. } \\
\text { - Computer Based Training } \\
\text { (CBT). } \\
\text { - Augmented Reality. } \\
\text { - Learn from anywhere / } \\
\text { Teach from anywhere } \\
\text { Mobile Devices. }\end{array}$ & $\begin{array}{l}\text { CPOS - } 9 \text { items } \\
\text { CEMC - } 16 \\
\text { items } \\
\text { CPOG - } 14 \\
\text { items }\end{array}$ \\
\hline
\end{tabular}


In order to adapt the questionnaire's formulation to the Portuguese language and the military context, three sequential stages were followed: (1) translation and retroversion, (2) pre-test and (3) pilot test. As the items were initially expressed in the English language, the retroversion was applied to guarantee a precise translation into Portuguese. Subsequently, a pre-test was applied, using a small number of respondents (focus group) to test the adequacy of the questions and their comprehension. This focal group, consisting of 10 subjects from each course (30 participants) suggested some modifications in the items of the questionnaire, in order to be better understood by the target population. After the pre-test, a pilot test was performed and submitted to all the individuals of the CPOS, CEMC and CPOG of the 2017/2018 school year, whose objective was to test the reliability of the items (consistency).

\section{Pilot Test Sample}

The pilot test universe consisted of 76 teachers and 225 students. The questionnaire was answered by 46 teachers and 150 students. After validation of the answers given, there were some errors and incongruities, which led to the elimination of some of them. The final number of validated respondents was 24 teachers and 124 students, corresponding respectively to $31.6 \%$ and $56.4 \%$ of the target population. Their demographic and professional characteristics can be seen in Table 3 .

Table 3. Characterization of the pilot test sample

\begin{tabular}{|c|c|c|c|c|c|c|c|c|}
\hline Type & Age & Gender & Branch & Effective Service Time & Years of Teaching & Teaching Training & Course & Number of Valid Samples \\
\hline \multirow[t]{7}{*}{ Teacher } & $36<$ age $<40=20 \%$ & Female $=4 \%$ & Navy $=16 \%$ & $16<\mathrm{YOS}<20=16 \%$ & $<1$ year $=24 \%$ & Yes $=32 \%$ & CPOS $=100 \%$ & 24 \\
\hline & $41<$ age $<45=60 \%$ & Male $=96 \%$ & Army $=52 \%$ & $21<\mathrm{YoS}<25=44 \%$ & $1<$ years $<3=52 \%$ & No $=68 \%$ & CEMC $=68 \%$ & \\
\hline & age $>51=20 \%$ & & Air Force $=32 \%$ & $26<\mathrm{YOS}<30=20 \%$ & $>3$ years $=24 \%$ & & $\mathrm{CPOG}=48 \%$ & \\
\hline & & & & YoS >51 = 20\% & & & & \\
\hline & Mean $=44,28$ & & & Mean $=25,68$ & & & & \\
\hline & $\operatorname{Min}=38$ & & & Min = 19 & & & & \\
\hline & $\operatorname{Max}=55$ & & & $\operatorname{Max}=37$ & & & & \\
\hline \multirow[t]{9}{*}{ Student } & age $<36=31,5 \%$ & Female $=17,7 \%$ & Navy $=38,7 \%$ & YoS $<16=26,6 \%$ & & Yes $=32 \%$ & CPOS $=81,5 \%$ & 124 \\
\hline & $36<$ age $<40=35,5 \%$ & Male = $82,3 \%$ & Army = 30,6\% & $16<Y o S<20=43,5 \%$ & & No $=68 \%$ & CEMC $=9,7 \%$ & \\
\hline & $41<$ age $<45=10,5 \%$ & & Air Force $=30,6 \%$ & $21<Y o S<25=6,5 \%$ & & & CPOG $=8,9 \%$ & \\
\hline & $46<$ age $<50=8,9 \%$ & & & $26<Y o S<30=11,3 \%$ & & & & \\
\hline & age $>51=13,7 \%$ & & & YoS >51 = 12,1\% & & & & \\
\hline & & & & Mean = 19,81 & & & & \\
\hline & Mean $=39,94$ & & & $\operatorname{Min}=9$ & & & & \\
\hline & $\operatorname{Min}=33$ & & & $\operatorname{Max}=35$ & & & & \\
\hline & $\operatorname{Max}=54$ & & & & & & & \\
\hline
\end{tabular}




\section{Pilot Test Preliminary Results}

As preliminary results from a pilot test, they should be interpreted as exploratory data for the preparation of the questionnaire that will be submitted to the target population of the study, CPOS, CEMC and CPOG students of the 2018/2019 school year.

Reliability was estimated by the Cronbach's alpha coefficient, and the items of the study achieved a reliable result (ILS> 0.60, use of ICT>0.97).

The answers to the questionnaire were therefore submitted to a first analysis, using the statistical package for the social sciences (SPSS V.23) with regard to statistics describing the method of comparative analysis of means, centred on two aspects: (1) Analysis of learning style profiles; and (2) Analysis of the barriers to the use of ICT in the "Classroom".

\section{Learning Styles Profiles Analysis}

Table 4 summarises the learning style profiles reported by students and teachers of each of the Courses under analysis (CPOS, CEMC and CPOG).

Table 4. Learning Style Profiles reported

\begin{tabular}{|l|l|l|l|l|l|}
\hline Sample & $\begin{array}{l}\text { Perception: } \\
\text { Sensory }\end{array}$ & Input: Visual & $\begin{array}{l}\text { Processing: } \\
\text { Active }\end{array}$ & $\begin{array}{l}\text { Understanding: } \\
\text { Sequential }\end{array}$ & $\mathbf{N}$ \\
\hline Students CPOS & $91 \%$ & $88 \%$ & $70 \%$ & $77 \%$ & 101 \\
\hline Students CEMC & $92 \%$ & $100 \%$ & $75 \%$ & $67 \%$ & 12 \\
\hline Students CPOG & $55 \%$ & $82 \%$ & $64 \%$ & $27 \%$ & 11 \\
\hline Sample & $\begin{array}{l}\text { Content: } \\
\text { Concrete }\end{array}$ & $\begin{array}{l}\text { Presentation: } \\
\text { Visual }\end{array}$ & $\begin{array}{l}\text { Student } \\
\text { participation: } \\
\text { Active }\end{array}$ & $\begin{array}{l}\text { Perspective: } \\
\text { Sequential }\end{array}$ & $\mathbf{N}$ \\
\hline Teachers CPOS & $62 \%$ & $60 \%$ & $61 \%$ & $60 \%$ & 24 \\
\hline Teachers CEMC & $50 \%$ & $58 \%$ & $58 \%$ & $59 \%$ & 17 \\
\hline Teachers CPOG & $67 \%$ & $64 \%$ & $60 \%$ & $78 \%$ & 11 \\
\hline
\end{tabular}

Table 4 reads as follows, for example, of the 101 CPOS students who completed ILS, $91 \%$ were classified as having a "sensory" profile (implying that $9 \%$ were classified as having an "intuitive" profile) $88 \%$ prefer "visual" input of content (so $12 \%$ prefer to "verbal" content input), and so on. 
It is verified that an expressive majority of the students of the CPOS and CEMC show preference for the "sensory", "Visual", "Active" and "Sequential" style. Regarding the CPOG students, an expressive majority shows a preference for the "Visual" style, but only a relative majority shows a preference for the "sensory" and "Active" style, even reversing the preference in the field of "Understanding" with a minority opting for the "Sequential" style.

With regard to how teachers perceive the learning styles of the students, it is verified that the majority follow the preferences expressed by them, however, with regard to the dimension "Understanding", a significant majority of teachers present a "Sequential" style, contrary to the majority of students.

The analysis of ILS responses also allows us to identify the degree of preference for a given learning style, which may be mild, moderate or strong, as shown in Table 5 .

Table 5. Learning Style Profiles reported

\begin{tabular}{|c|c|c|c|c|c|c|c|c|c|c|c|c|}
\hline \multirow[b]{2}{*}{ Sample } & \multicolumn{3}{|c|}{$\begin{array}{l}\text { Perception: } \\
\text { Sensorial - Intuitive }\end{array}$} & \multicolumn{3}{|c|}{\begin{tabular}{|l|} 
Input: \\
Visual - Verbal \\
\end{tabular}} & \multicolumn{3}{|c|}{$\begin{array}{l}\text { Processing: } \\
\text { Active - Reflexive }\end{array}$} & \multicolumn{3}{|c|}{$\begin{array}{l}\text { Understanding: } \\
\text { Sequential - Global }\end{array}$} \\
\hline & $\begin{array}{l}\text { Mod/ } \\
\text { Str } \\
\text { Sen } \\
\end{array}$ & Mild & \begin{tabular}{|l} 
Mod/ \\
Str \\
Int \\
\end{tabular} & \begin{tabular}{|l|} 
Mod/ \\
Str \\
Vis \\
\end{tabular} & Mild & \begin{tabular}{|l|} 
Mod/ \\
Str \\
Ver \\
\end{tabular} & $\begin{array}{l}\text { Mod// } \\
\text { Str } \\
\text { Ati } \\
\end{array}$ & Mild & $\begin{array}{l}\text { Mod// } \\
\text { Str } \\
\text { Ref } \\
\end{array}$ & $\begin{array}{l}\text { Mod/ } \\
\text { Str } \\
\text { Seq } \\
\end{array}$ & Mild & $\begin{array}{l}\text { Mod/ } \\
\text { Str } \\
\text { Glo } \\
\end{array}$ \\
\hline $\begin{array}{l}\text { Students } \\
\text { CPOS }\end{array}$ & $65 \%$ & $31 \%$ & $4 \%$ & $75 \%$ & $20 \%$ & $5 \%$ & $34 \%$ & $53 \%$ & $13 \%$ & $42 \%$ & $50 \%$ & $8 \%$ \\
\hline $\begin{array}{l}\text { Students } \\
\text { CEMC }\end{array}$ & $75 \%$ & $17 \%$ & $8 \%$ & $83 \%$ & $17 \%$ & $0 \%$ & $33 \%$ & $67 \%$ & $0 \%$ & $17 \%$ & $75 \%$ & $8 \%$ \\
\hline $\begin{array}{l}\text { Students } \\
\text { CPOG }\end{array}$ & $18 \%$ & $55 \%$ & $27 \%$ & $73 \%$ & $9 \%$ & $18 \%$ & $9 \%$ & $82 \%$ & $9 \%$ & $9 \%$ & $55 \%$ & $36 \%$ \\
\hline \multirow{2}{*}{ Sample } & \multicolumn{3}{|c|}{$\begin{array}{l}\text { Content: } \\
\text { Concrete - Abstract }\end{array}$} & \multicolumn{3}{|c|}{$\begin{array}{l}\text { Presentation: } \\
\text { Visual - Verbal }\end{array}$} & \multicolumn{3}{|c|}{$\begin{array}{l}\text { Student } \\
\text { participation: } \\
\text { Active - Passive } \\
\end{array}$} & \multicolumn{3}{|c|}{$\begin{array}{l}\text { Perspective: } \\
\text { Sequential - Global }\end{array}$} \\
\hline & $\begin{array}{l}\text { Mod/ } \\
\text { Str } \\
\text { Con } \\
\end{array}$ & Mild & $\begin{array}{l}\text { Mod/ } \\
\text { Str } \\
\text { Abs }\end{array}$ & \begin{tabular}{|l|} 
Mod/ \\
Str \\
Vis \\
\end{tabular} & Mild & \begin{tabular}{|l|} 
Mod/ \\
Str \\
Ver \\
\end{tabular} & $\begin{array}{l}\text { Mod// } \\
\text { Str } \\
\text { Ati } \\
\end{array}$ & Mild & $\begin{array}{l}\text { Mod// } \\
\text { Str } \\
\text { Pas } \\
\end{array}$ & \begin{tabular}{|l|} 
Mod/ \\
Str \\
Seq \\
\end{tabular} & Mild & $\begin{array}{l}\text { Mod/ } \\
\text { Str } \\
\text { Glo }\end{array}$ \\
\hline $\begin{array}{l}\text { Teachers } \\
\text { CPOS }\end{array}$ & $33 \%$ & $54 \%$ & $13 \%$ & $50 \%$ & $17 \%$ & $33 \%$ & $50 \%$ & $17 \%$ & $33 \%$ & $13 \%$ & $83 \%$ & $4 \%$ \\
\hline $\begin{array}{l}\text { Teachers } \\
\text { CEMC }\end{array}$ & $12 \%$ & $82 \%$ & $6 \%$ & $24 \%$ & $41 \%$ & $35 \%$ & $12 \%$ & $82 \%$ & $6 \%$ & $12 \%$ & $76 \%$ & $12 \%$ \\
\hline $\begin{array}{l}\text { Teachers } \\
\text { CPOG }\end{array}$ & $18 \%$ & $82 \%$ & $0 \%$ & $45 \%$ & $45 \%$ & $9 \%$ & $18 \%$ & $82 \%$ & $0 \%$ & $9 \%$ & $91 \%$ & $0 \%$ \\
\hline
\end{tabular}


Table 5 shows that a large percentage of students and teachers have a mild preference for a particular learning style. This suggests that both students and teachers may be able to switch between styles, adapting more easily to the "classroom" environment.

However, in the case of the students of all the courses, there is a moderate or strong preference for the "Visual" style in the "Input" dimension, and also, in the case of the CPOS and CEMC students, a moderate or strong style preference of "Sensory" perception, not being followed by the teachers in this preference. Particular attention should be given to these situations.

In order to develop a comparative analysis between preferences of learning styles and teaching styles between students and teachers, the results of the ILS questionnaire were transformed into a 7-point Likert scale, according to Figure 1.

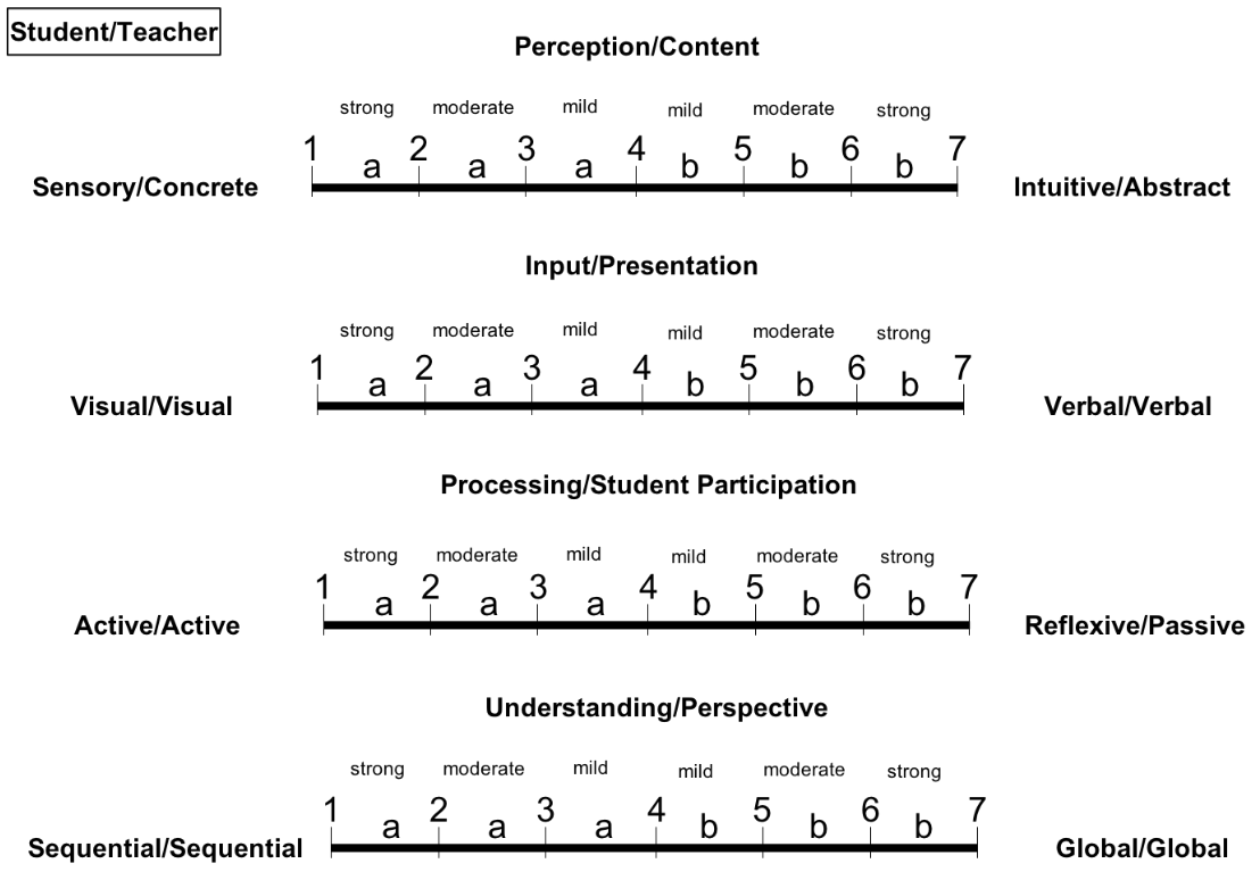

Figure 1. ILS results conversion scale

Therefore, with regard to learning and teaching styles (Graph 1), in global terms, there were some differences between teachers and students. 
The results indicate the following preferences and attitudes:

- Students have a mild preference for actively processing information and teachers also have a mild preference for active student participation.

- Students have a moderate preference for types of sensory information and teachers have only a mild preference for the transmission of concrete information.

- Students have a moderate preference for using the visual sensitive channel to perceive the information and teachers have only a mild preference for the visual presentation of the information.

- Students have a mild preference to perceive information sequentially and teachers also have a mild preference for the sequential presentation of information.

\section{INDEX OF LEARNING / TEACHING STYLES}

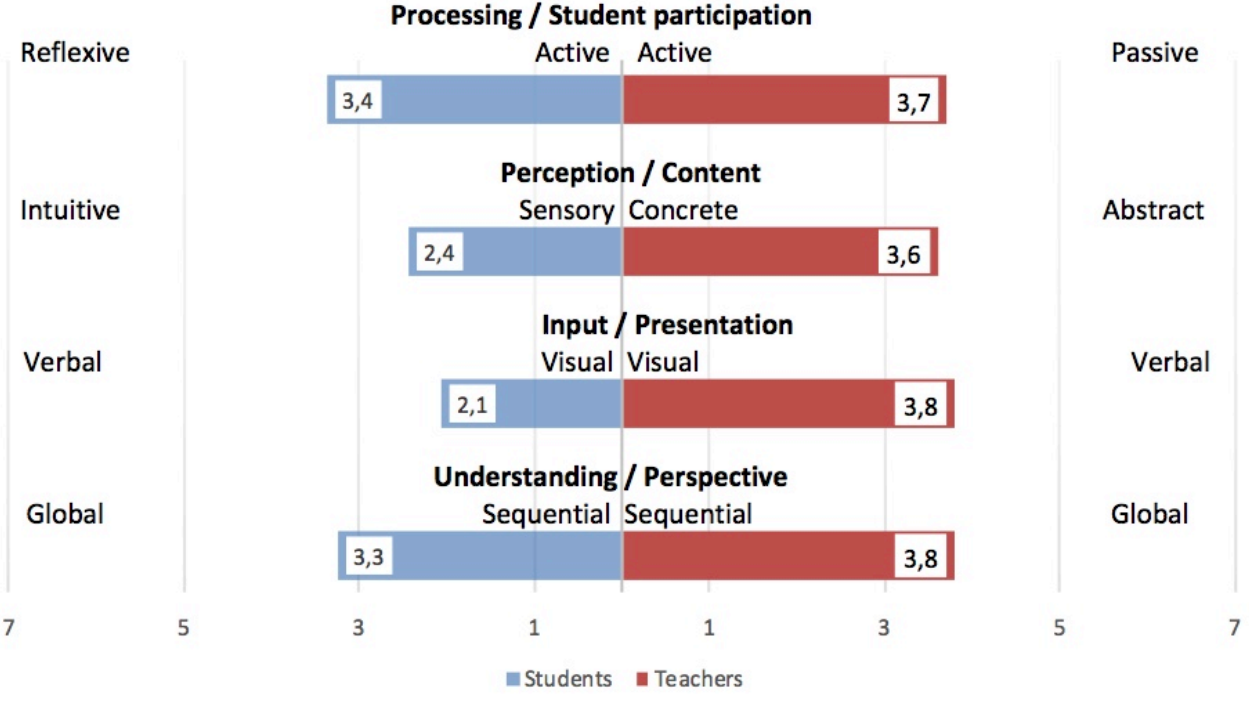

Graph 1. Index of Learning / Teaching Styles

When analysed according to the gender of the respondents (Graph 2), the results indicate the following preferences and attitudes:

- In the students, both genders have a mild preference for processing the information actively, and in the teachers, both genders also have a mild preference for the active participation of the students.

- In students, both genders have a moderate preference for types of sensory information, and in teachers, the male gender has a mild preference for the transmission of 
concrete information, but the female gender already has a moderate preference for the transmission of concrete information.

- In the students, the female gender has a moderate preference for using the visual sensory channel to perceive the information, which becomes strong in the masculine gender, and in the teachers, the male gender has only a mild preference for the visual presentation of the information, which becomes moderate in the female gender.

- In the students, both genders have a mild preference for perceiving the information sequentially, and in teachers, the masculine gender also has a mild preference for the sequential presentation of the information, which becomes moderate in the feminine gender.

INDEX OF LEARNING / TEACHING STYLES BY GENDER

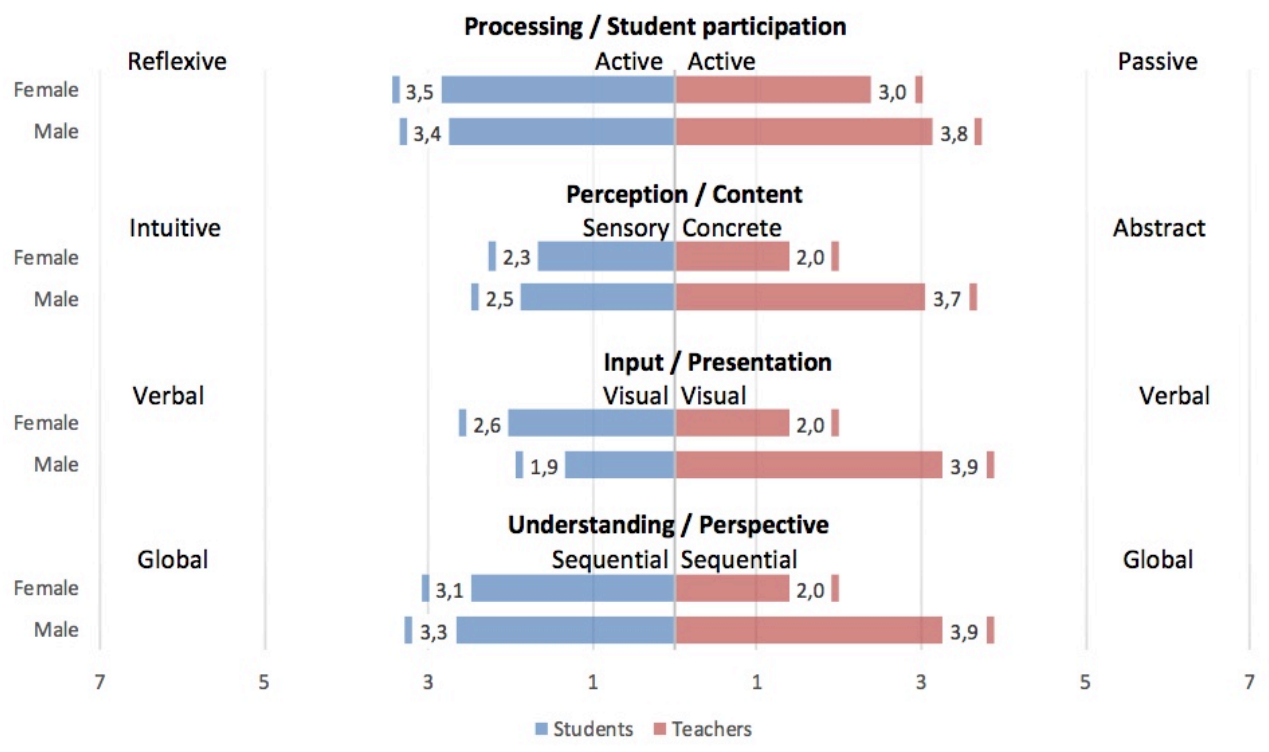

Graph 2. Index of Learning / Teaching Styles - by Gender Index

When analysed according to the branch of the Armed Forces to which the respondents belong (Graph 3), the results indicate the following preferences and attitudes: 
INDEX OF LEARNING / TEACHING STYLES BY BRANCH OF THE ARMED FORCES

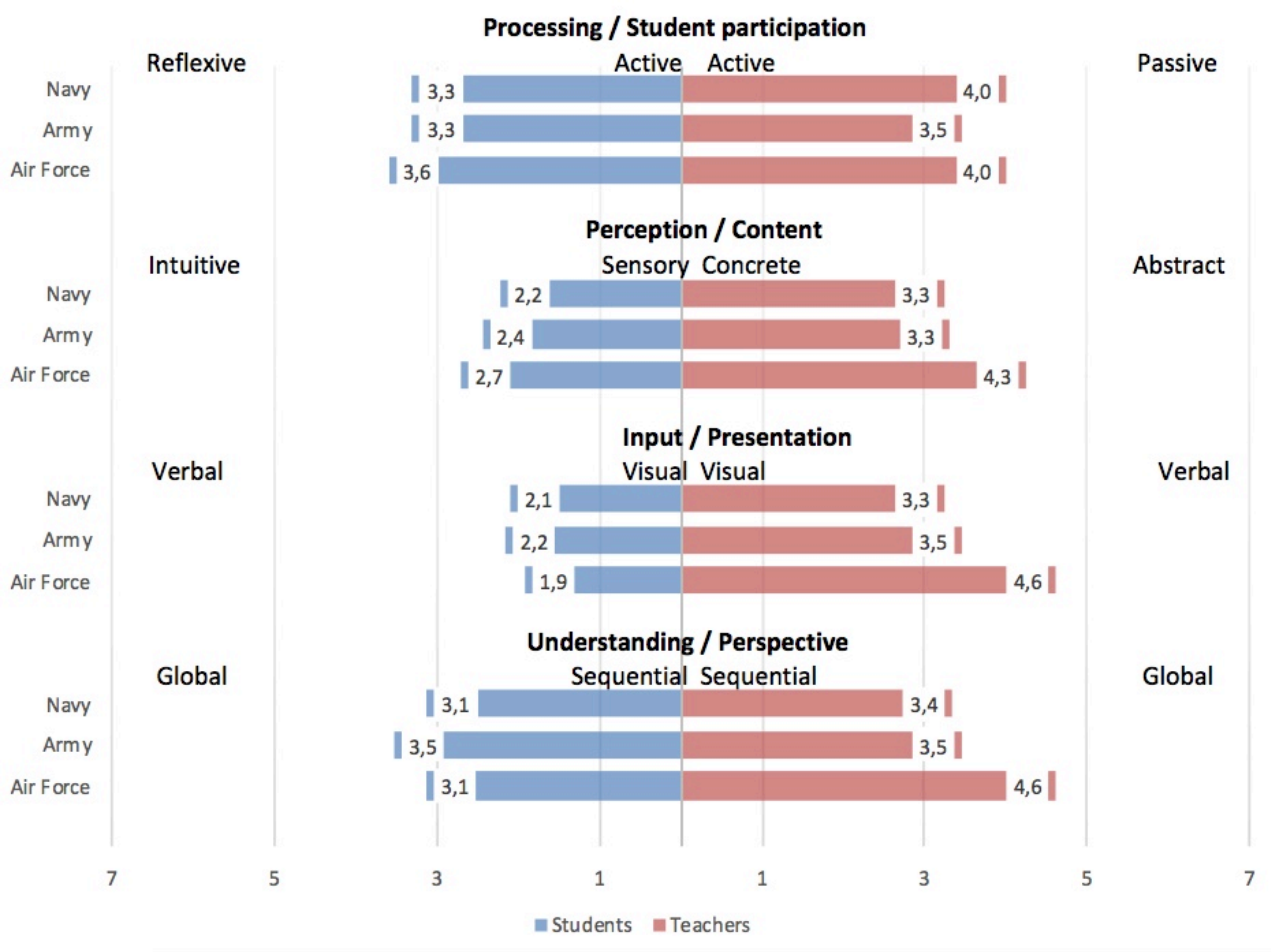

Graph 3. Index of Learning / Teaching Styles - by Branch of the Armed Forces

- There are no significant differences by branch of the Armed Forces, in the light preferences of the students for processing the information actively and in the light preferences of the teachers for the active participation of the students.

- There are no significant differences by branch of the Armed Forces, in the moderate preference of the students for the types of sensorial information; Navy and Army teachers have a mild preference for the transmission of concrete information, but Air Force teachers have a mild preference for the transmission of abstract information.

- Navy and Army students have a moderate preference for using the visual sensitive channel to perceive the information, which becomes strong in Air Force students; Navy and Army teachers have a mild preference for the visual presentation of information, but Air Force teachers have a mild preference for the verbal presentation of information. 
- There are no significant differences by branch of the Armed Forces, in the mild preference of the students for perceiving the information sequentially; Navy and Army teachers have a mild preference for the sequential presentation of information, but Air Force teachers have a mild preference for the overall presentation of information.

When analysed according to the age group to which the respondents belong (Graph 4), the results indicate the following preferences and attitudes:

\section{INDEX OF LEARNING / TEACHING STYLES} BY AGE GROUP

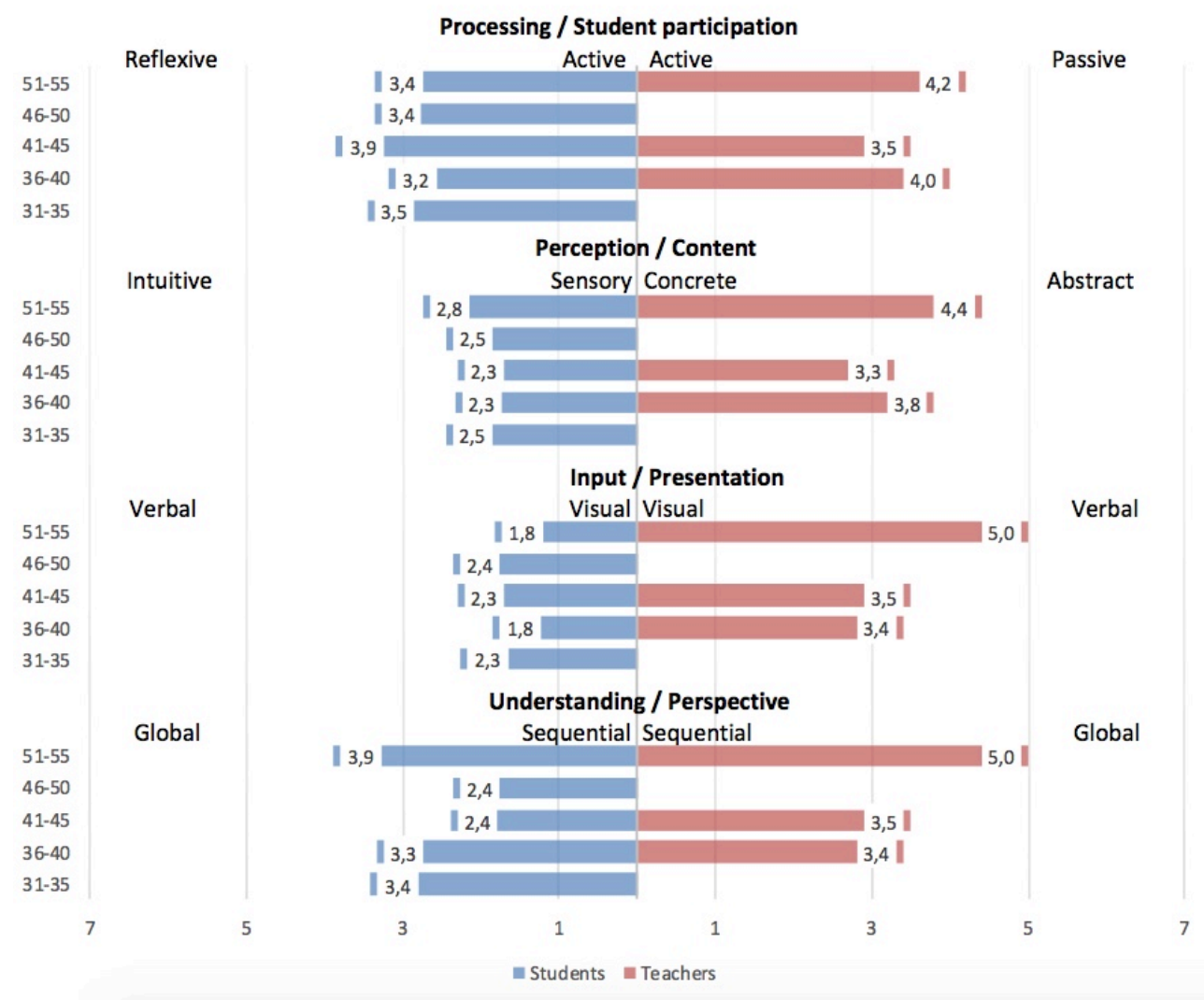

Graph 4. Index of Learning / Teaching Styles - By Age Group

- There are no significant differences by age group in the light preferences of the students for processing the information actively and in the light preferences of the teachers for the active participation of the students, except in the 51-55 age group in which the teachers show a mild preference for the passive participation of the students. 
- There are no significant differences by age group, the moderate preference of students for types of sensory information and the mild preference of teachers for the transmission of concrete information, except in the 51-55 age group where teachers show a mild preference for transmission of abstract information.

- There are no significant differences according to the age group, the moderate preference of the students for the use of the visual sensory channel for perceiving the information, and the teachers' mild preference for the visual presentation of the information, except in the 51-55 age bracket, teachers show a mild preference for the transmission of verbal information.

- There are no significant differences by age group, the students' mild preference for perceiving the information sequentially and the teachers' mild preference for the sequential presentation of the information, except in the 51-55 age group where teachers show a mild preference for the overall presentation of the information.

- When analysed according to the course the respondents attend / teach (Graph 5), the results indicate the following preferences and attitudes:

- There are no significant differences per course in the mild preferences of students for processing information actively and in the mild preferences of teachers for the active participation of students.

- There are no significant differences in the course, in the teachers' mild preference for the transmission of concrete information and in the moderate preference of the students for the types of sensory information, except in the CPOG in which the students show a mild preference for the transmission of sensory information.

- There are no significant differences in course, in the teachers' mild preference for the visual presentation of the information and in the students' moderate preference for using the visual sensory channel to perceive the information, except in the CEMC where students show a strong preference for transmission of visual information.

- There are no significant differences in course, in the teachers' mild preference for the sequential presentation of the information and in the students' mild preference for perceiving the information sequentially, except in the CPOG in which the students show a mild preference for the overall presentation form of the information. 


\section{INDEX OF LEARNING / TEACHING STYLES}

\section{BY COURSE}

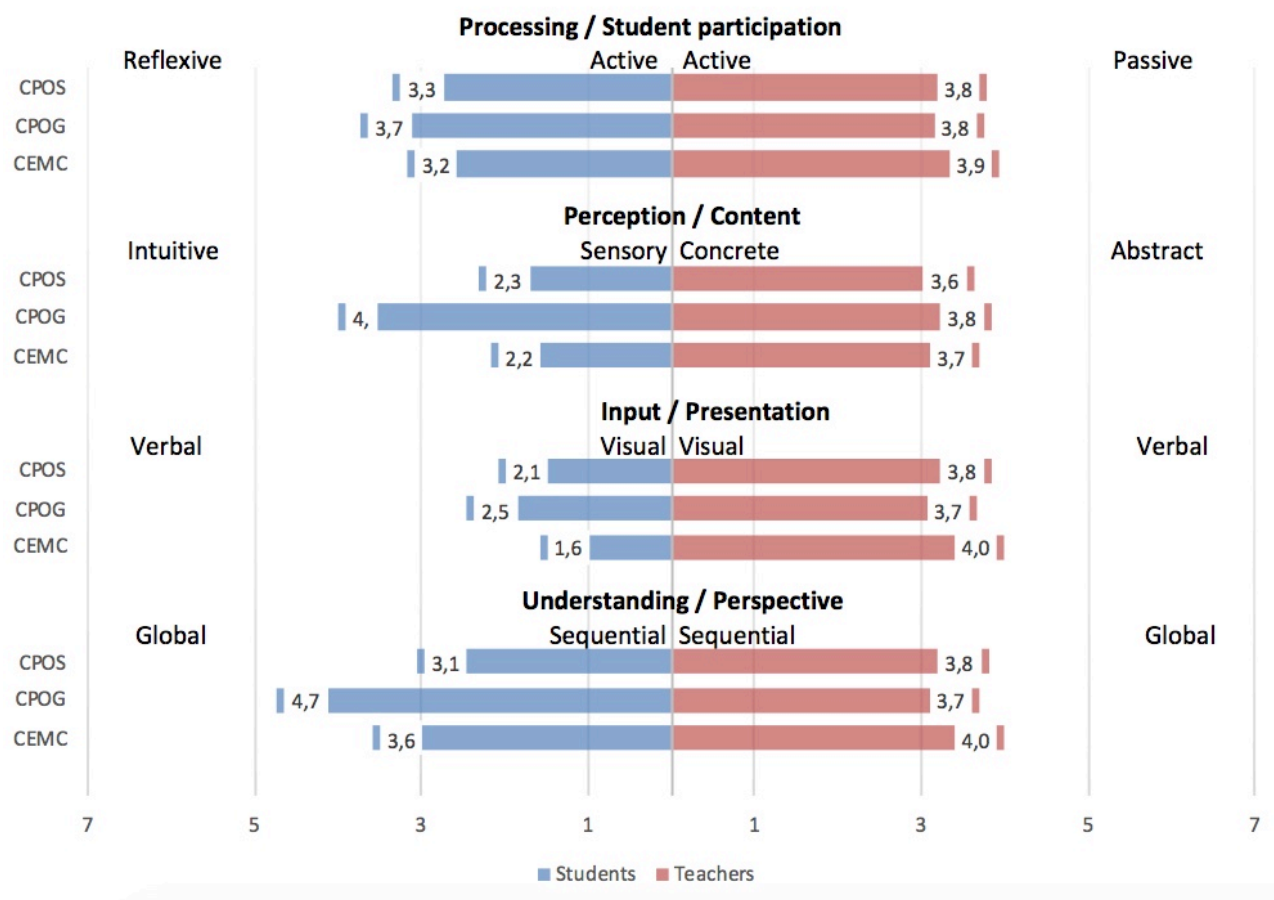

Graph 5. Learning / Teaching Styles Index - by Course

When analysed according to the effective service time (TSE) to which the respondents belong (Graph 6), the results indicate the following preferences and attitudes:

- There are no significant differences by TSE level in the light preferences of students for processing information actively and in the light preferences of teachers for the active participation of students, except in the 31-35 year old range in which teachers reveal a mild preference for passive student participation.

- There are no significant differences by TSE level, moderate student preference for types of sensory information, and teachers' mild preference for the transmission of concrete information, except in the 31- to 35-year-old age range where teachers show a mild preference for the transmission of abstract information.

- There are no significant differences by TSE rank, the moderate preference of the students for the use of the visual sensory channel to perceive the information, and the teachers' mild preference for the visual presentation of the information, except in the 
31-35 year age group in which teachers show a mild preference for the transmission of verbal information.

- There are no significant differences by TSE rank, the students 'mild preference for perceiving the information sequentially, and the teachers' mild preference for the sequential presentation of the information, except in the 31-35 year old group where the teachers reveal a mild preference for the overall presentation of the information.

\section{INDEX OF LEARNING / TEACHING STYLES POR EFFECTIVE SERVICE TIME}

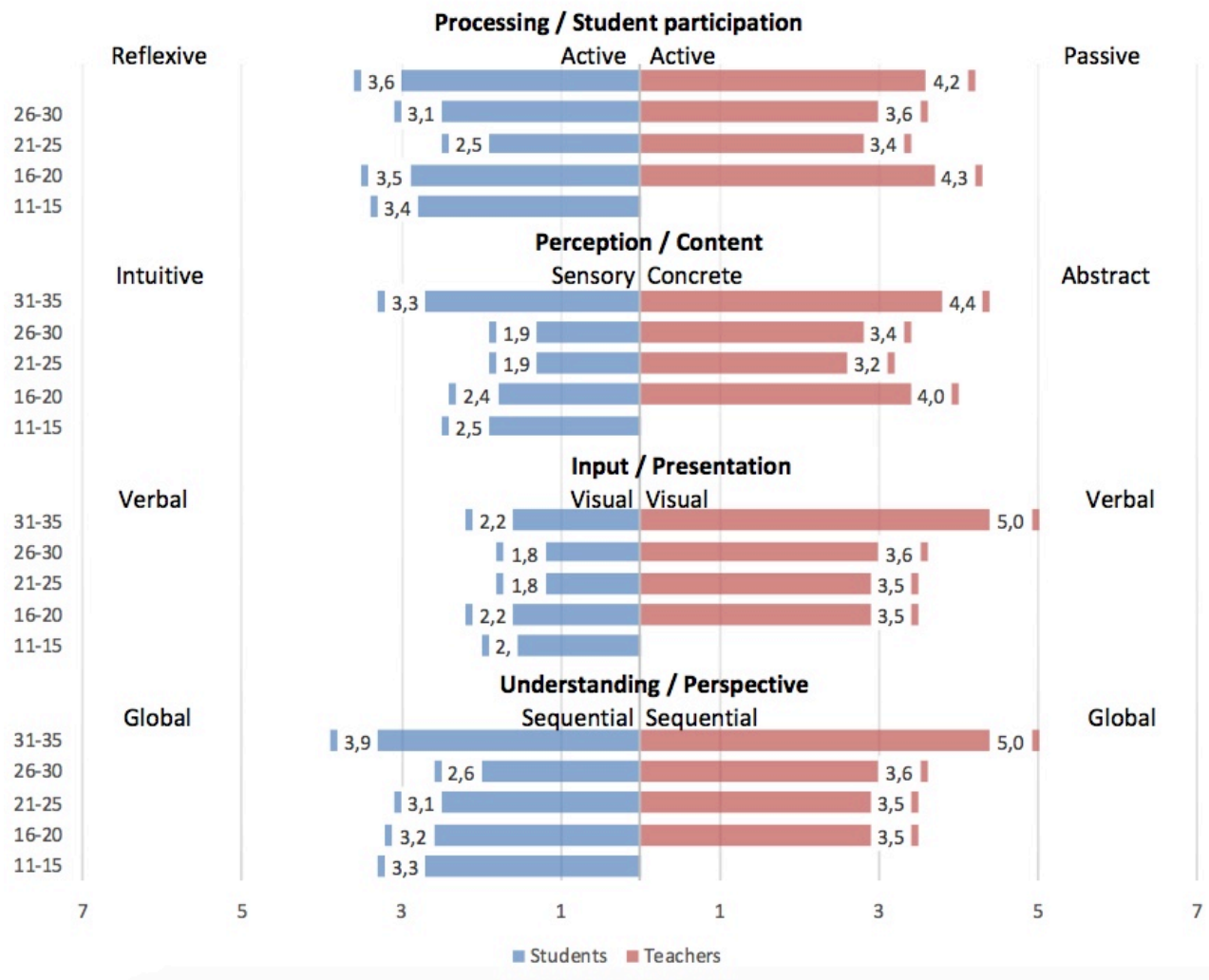

Graph 6. Learning / Teaching Styles Index - by Effective Time of Service 


\section{Analysis of Barriers to the use of ICT in the "Classroom"}

Acceptance of technology results from users' beliefs and attitudes about their use, which was measured with the perceived utility and perceived ease of use in the technology acceptance model (TAM) (Davis 1985, Venkatesh et al. 2003).

The outcome expectation (OE) is pointed out in several empirical studies as the most important predictor of the use of technology (Venkatesh et al. 2003, Kim et al. 2007, Lee 2010).

The task-technology fit (TTF) is the degree to which a technology helps an individual perform his or her tasks (Goodhue and Thompson 1995). The TTF assumption is that users accept the technology because of their potential benefits, such as performance improvement, regardless of their attitude.

From the point of view of social psychology, the dominant social factor (SF) is a kind of social norm defined as perceived social pressure to carry out behaviour or not (Ajzen 1991). Studies suggest that perceived social influence has a significant positive influence on individual beliefs about the usefulness of technology and positively and significantly affects the use of ICTs (Lewis et al. 2003, Kim et al. 2007, Thompson et al. 2007).

Personal factors (PF) include computer self-efficacy and personal innovation through technology, widely recognised as explanatory factors that influence the use of IT by endusers (Lewis et al. 2003, Thompson et al. 2007).

Given the results of the data collected, both pupils and teachers indicate a good outcome expectation with the use of ICT in the "Classroom", consider ICT reasonably adjusted for use in the context of professional military training, consider themselves capable of using and consequently accept the introduction of technology into teaching and learning processes. The brodening of this study will allow us to see how concretely it can be done (Graph 7). 


\section{BARRIERS TO THE USE OF ICT IN THE "CLASSROOM"}

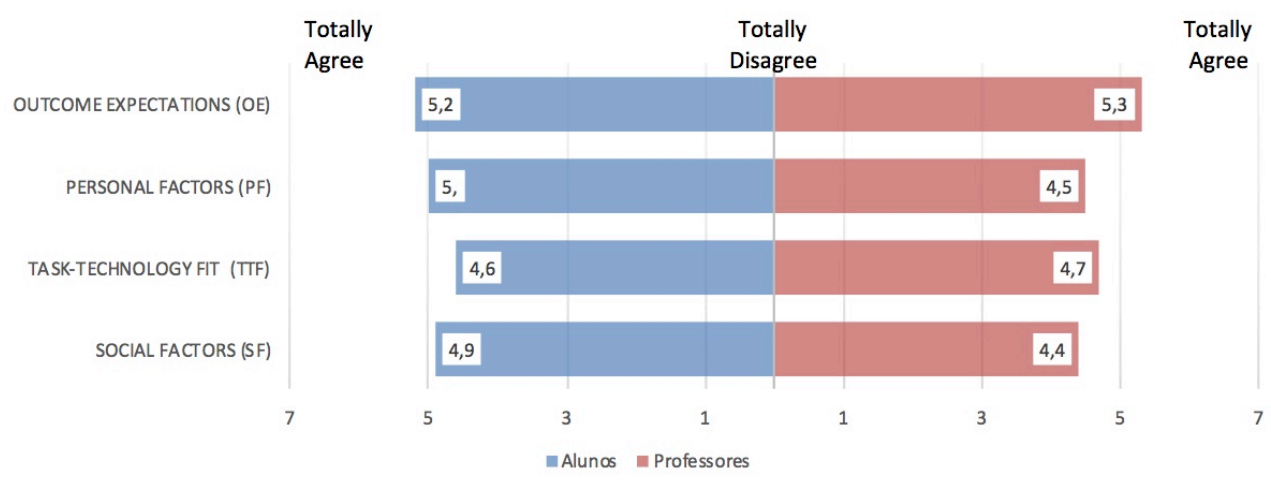

Graph 7. Barriers to the use of ICT in the "Classroom"

\section{Conclusions}

Being part of a broader research on teaching and learning methodologies in military higher education, through an approach to the introduction of technologies in the classroom, this paper has essentially sought to develop the conceptual framework and its interconnection with the methodological strategy, that is the definition of the instruments of data collection for the complete empirical study to be developed.

In this sense, a data collection instrument was prepared based on the following scales: (1) Index of Learning Styles (ILS), proposed by Soloman and Felder (2012); and (2) Technology Acceptance Barriers (TAB), proposed by Gu, Zhu, and Guo (2013), supplemented with ad hoc items, designed to collect some biographical and professional data from the respondents and to verify which are the currently used traditional teaching methodologies in curricular areas, and to identify ICT-based teaching methodologies that teachers and students consider more appropriate to each of the specific curricular areas.

The results presented refer to the pilot validation test of these same data collection instruments.

The first stage of preparation of data collection instruments is in the process of being finalised, but a preliminary analysis indicates that: 
- The adapted ILS scale has an acceptable internal consistency (alpha>0.60) and the adapted TAB scale has a very good internal consistency (alpha> 0.97);

- In general, students and teachers share the same teaching-learning styles; however, when analysed according to control variables, there are significant differences;

- Both students and teachers show a good propensity to use ICT in the classroom.

In the light of these preliminary results, the analysis of the data already collected will be further analysed in the continuation of the study, and it will be sought to gather more information and advance to the third objective of the study, which is to identify ICTs that can be used in classroom in the military context.

\section{References}

Ajzen, I., 1991. The theory of planned behavior. Orgnizational Behavior and Human Decision Processes, 50, 179-211.

Bielewicz, M. and Pietrakowski, P., 2016. The Strategic Partnership Project 'Creating international semester regarding military education needs for future offcers in Europe.

Bower, M., Hedberg, J., and Kuswara, A., 2010. A framework for Web 2.0 learning design. Educational Media International, 47 (3), 177-198.

Bryman, A., 1988. Quantity and Quality in Social Research. New York: Routledge.

Creswell, J., 2012. Educational research: Planning, conducting, and evaluating quantitative and qualitative research. 4th ed. University of Nebraska-Lincoln.

Creswell, J., 2013. Research Design: Qualitative, quantitative, and mixed methods approaches. 2nd ed. Sage publications.

Davis, F.D., 1985. A technology acceptance model for empirically testing new end-user information systems: Theory and results. PhD dissertation. Massachusetts Institute of Technology.

Denning, P.J. and Higgins, S.L., 2015. Being in Uncertainty: Cultivating a New Sensibility in Military Education. In: R. Doughty, L.I. Wells, and T. Hailes, eds. Innovative Learning: A Key to National Security. 133-154.

Downes, C., 2015. Rapidly Evolving, Digitally-Enabled Learning Environments: Implications for Institutional Leaders, Educators and Students. In: R. Doughty, L. Wells, and T. Hailes, eds. Innovative Learning: A Key to National Security. Army Press, 101-132.

EEAS, 2018. Sectoral Qualifications Framework for the Military Officer Profession - European External Action Service [online]. News stories. Available from: https://eeas.europa.eu/ headquarters/headquarters-homepage_en/52208/Sectoral Qualifications Framework for the Military Officer Profession [Accessed 2 Feb 2019].

Exército Português, 2014. Manual Didático (MD) 240-01 Qualidade da Formação.

Felder, R. and Silverman, L., 1988. Learning and Teaching Styles In Engineering Education. Engeneering Education, 78 (7), 674-681. 
Felder, R. and Silverman, L., 2002. Learning and Teaching Styles In Engineering Education.

Felder, R. and Spurlin, J., 2005. Application, Reliability and Validity of the Index of Learning Styles. International Journal of Engineering Education, 21 (1), 103-112.

Foon Hew, K. and Sum Cheung, W., 2013. Use of Web 2.0 technologies in K-12 and higher education: The search for evidence-based practice.

Garrido, A., 2006. Errar é humano! A vivência de erros e seus efeitos na produção oral sob a perspectiva do aluno de Inglês como Língua Estrangeira.pdf. PUC - Rio.

Goodhue, D.L. and Thompson, R.L., 1995. Task-technology fit and individual performance. MIS Quarterly.

Gu, X., Zhu, Y., and Guo, X., 2013. Meeting the "Digital Natives": Understanding the Acceptance of Technology in Classrooms. Source: Journal of Educational Technology \& Society, 16 (1), 392-402.

Karnad, A., 2013. Student Use of Recorded Lectures.

Kim, C., Jahng, J., and Lee, J., 2007. An empirical investigation into the utilization-based information technology success model: Integrating task-performance and social influence perspective. Journal of Information Technology, 22 (2), 152-160.

Lee, M.C., 2010. Explaining and predicting users' continuance intention toward e-learning: An extension of the expectation-confirmation model. Computers and Education, 54 (2), 506-516.

Lewin, C. and McNicol, S., 2014. Criar a Sala de Aula do Futuro: conclusóes do projeto iTEC.

Lewis, W., Agarwal, R., and Sambamurthy, V., 2003. Sources of influence on beliefs about information technology use: An empirical study of knowledge workers. MIS quarterly, 657678.

Low, M.L., 2017. Technology That Will Shape Education In 2017 [online]. Education Technology Solutions. Available from: https://educationtechnologysolutions.com/2017/03/technologywill-shape-education-2017/ [Accessed 2 Feb 2019].

Ministério da Defesa Nacional, 2015. Estatuto dos Militares das Forças Armadas (Decreto-Lei n. ${ }^{\circ}$ 90/2015). Diário da Répiblica.

Moskos, C.C., Williams, J.A., and Segal, D.R., 2000. The postmodern military: Armed forces after the Cold War. Oxford University Press on Demand.

Neal, D.J., 2015. Technology and its Impact on Defense/Security Thinking and Learning Intervention Issues. In: R. Doughty, L.I. Wells, and T. Hailes, eds. Innovative Learning: A Key to National Security. 155-170.

Pinel, S., 2017. Bringing It All Together: Literacy, ICT and the 21st Century Skills [online]. Education Technology Solutions. Available from: https://educationtechnologysolutions. com/2017/06/bringing-it-all-together-literacy-ict-and-the-21st-century-skills/ [Accessed 2 Feb 2019].

Quivy, R. and Campenhoudt, L., 2008. Manual de Investigação em Ciências Sociais. 5 a Edição. Trajetos. Lisboa: Gradiva.

Santos, L. and Lima, J., 2016. Orientaçóes metodológicas para a elaboração de trabalhos de investigação. Cadernos do IESM. Lisboa.

Schatz, S., Fautua, D.T., Stodd, J., and Reitz, E., n.d. The Changing Face of Military Learning. The Army Press. 
Soloman, B.A. and Felder, R., 1996. Index of learning styles questionnaire, NC State University. North Carolina State University, (January 1999), 1-5.

Soloman, B.A. and Felder, R., 1999. Index of Learning Styles Questionnaire [online]. Available from: https://www.webtools.ncsu.edu/learningstyles/ [Accessed 2 Feb 2019].

Thompson, R., Compeau, D., Higgins, C., and Lupton, N., 2007. Intentions to use information technologies: an integrative model. End User Computing Challenges and Technologies: Emerging Tools and Applications: Emerging Tools and Applications, 18 (3), 79-101.

Venkatesh, V., Smith, R.H., Morris, M.G., Davis, G.B., Davis, F.D., and Walton, S.M., 2003. USER ACCEPTANCE OF INFORMATION TECHNOLOGY: TOWARD A UNIFIED $V I E W$. User Acceptance of IT MIS Quarterly.

\section{Authors:}

Lúcio Agostinho Barreiros dos Santos, Col.

Military University Institute Research and Development Centre (CIDIUM), Military University Institute, Centre for Research in Organizations, Markets, and Industrial Management (COMEGI) Lusíada University of Lisbon, Lisbon, Portugal

https://orcid.org/0000-0002-3191-4409

Nuno Alberto Rodrigues Santos Loureiro, Lt. Col.

Military University Institute Research and Development Centre (CIDIUM), Military University Institute, Faculty of Sciences and Technology, NOVA University of Lisbon, Lisbon, Portugal

Joaquim Manuel Martins do Vale Lima, Col.

Military University Institute, Lisbon, Portugal

José Augusto de Sousa Silveira, Maj.

Military University Institute, Lisbon, Portugal

Rui José da Silva Grilo, Lt. Col.

Military University Institute, Lisbon, Portugal 